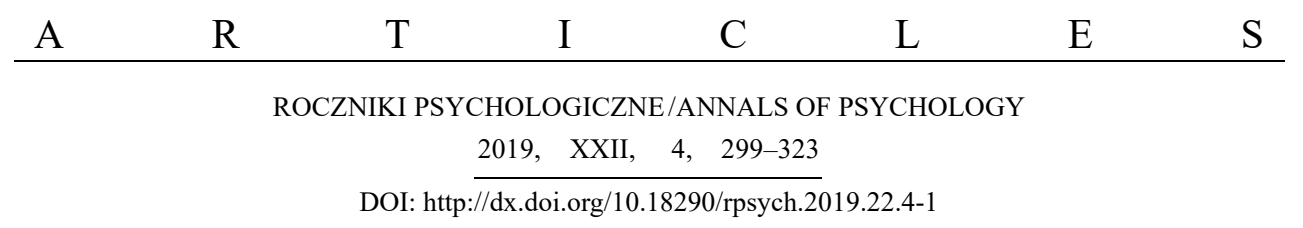

\author{
aZOFIA MAZUR \\ bRAFAŁ LAWENDOWSKI \\ aThe John Paul II Catholic University of Lublin, Poland \\ Institute of Psychology \\ ${ }^{b}$ University of Gdańsk, Poland \\ Institute of Psychology
}

\title{
CREATING, PRACTICING, AND REACTING TO MUSIC: A CONTENT ANALYSIS OF RESEARCH
}

Psychology of music, a science of the relations between humans and sound structures, is continuously developing. Given the growing number of publications in this domain, reviews of the literature are of value, as they integrate knowledge, informing and guiding future research endeavors. This article presents the results of a 47-year (1973-2019) content analysis of research on creating, practicing, and responding to music featured in The Psychology of Music journal. The purpose of our study was to identify and describe the themes in research on creating, practicing, and responding to music, indicating which study topics were the most often present in publications. We identified 17 categories of research topics and found that the largest number of publications dealt with predictors of music creating, self-regulated practice, or affective responses to music. Suggestions for developing and bolstering research and practice are provided.

Keywords: creating music; musical practice; reactions to music; literature review; content analysis; psychology of music.

Corresponding Author: Correspondence concerning this article should be addressed to ZOFIA MAZUR - The John Paul II Catholic University of Lublin, Institute of Psychology, Al. Racławickie 14, 20-950 Lublin, Poland; e-mail address: zsmazur@gmail.com

Funding Source: This research was financed by the National Science Centre, Poland, grant no. DEC-2018/29/N/HS6/02641.

We thank Prof. Mariola Łaguna (The John Paul Catholic University of Lublin) for her comments that helped us improve this paper and for her support in editing this issue. 


\section{INTRODUCTION}

Music appears when the construction of sounds is created and recognized with pleasure (Rakowski, 2001). Among many disciplines dealing with sound structure, such as music education or music theory and analysis (Ockelford, 2016), psychology of music ${ }^{1}$ is a science about humans as music creators (Hart \& Di Blasi, 2013; Kozbelt, 2007), performers (Barry, 1992; Miksza, 2013), and listeners (Rickard, 2004; Bennett \& Ginsborg, 2018) and about the two-way relations between them and music (Manturzewska, 1990).

Being a distinct discipline, psychology of music is at the same time a highly integrative and multidisciplinary field (Ockelford, 2016). This is reflected in the aims of one of the key journals devoted to this area, namely Psychology of Music $(P o M)$. This journal seeks to "increase the scientific understanding of all psychological aspects of music and music education" and to publish "studies on listening, performing, creating, memorizing, analyzing, learning and teaching as well as applied social, developmental, attitudinal and therapeutic studies" (PoM, 2019).

In this article we decided to focus only on three research areas and describe their contents. The purpose of our study was to identify and describe the themes in present in the studies on creating, practicing, and responding to music published in $P o M .^{2}$ We aimed to answer following research questions: (1) What are the topics of studies on creating, practicing, and responding to music published in the PoM journal? (2) Which study topics were published the most often in PoM? (3) What are the major aims of studies addressing each topic?

In order to answer research questions, we first briefly outline the issues involved in creating, practicing, and responding to music. Next, we present an analysis of PoM literature. As this is an introductory paper to the special issue of Annals of Psychology $(A o P)$ on musical creation, music practice, and reactions to music, in the Conclusions section we outline the contents of papers included in this issue.

1 In this article we use the terms "psychology of music" and "music psychology" interchangeably.

${ }^{2}$ We chose PoM because it is currently the most prestigious journal in the field of music psychology, with the highest impact factor $(\mathrm{IF}=1.38)$ compared to other journals, such as Music Education Research (IF = 0.83), Musicae Scientiae (IF = 1.25), or Music Perception (IF = 1.15). 


\section{Creating, Practicing, and Responding to Music}

One of the areas of research devoted to the understanding of music and human relationship is the process of engaging in music creative activities. In psychology, creativity is viewed as "the generation of ideas, insights, or problem solutions that are both novel and potentially useful" (Baas, De Dreu, \& Nijstad, 2008, p. 780). Creative musical activities include spontaneous behaviors, composition, and improvisation (Ryan \& Brown, 2012). Musicians may, for example, perform a familiar piece in a new expressive way, which makes it sound spontaneous (Keller, Weber, \& Engel, 2011), they may compose-with pen and paper, using revision and hard work to eliminate or avoid mistakes, and they may also improvise, that is, perform newly created music in "real time" (Larson, 2005). Musical composition and improvisation can be performed individually or with a group of people (e.g., during jam sessions; Wilson \& MacDonald, 2012).

Psychology also offers musicians some points of reference in their everyday activities such as their home practice, which consists in physically and/or mentally repeated musical performance (Mielke, 2016). Researchers distinguish formal (deliberate) practice - that is, effortful, focused on improvement of musical skills - and informal practice, which is a playful activity, without an explicit aim to improve (Ericsson, Krampe, \& Tesch-Roemer, 1993; Sloboda, Davidson, Howe, \& Moore, 1996). Self-regulated learning (SRL) is a process in which students actively strive to acquire academic skills (Zimmerman, 2002), also in the domain of music; it requires using metacognitive strategies (e.g., goal setting, planning) and task-specific cognitive strategies (e.g., slow repetition) as well as management strategies (e.g., avoiding distractions) to attain goals (BonnevilleRoussy \& Bouffard, 2015). Management strategies are an essential feature of metaknowledge and metacognitive self (Lawendowski, Kierzkowski, \& Karasiewicz, 2016).

Music psychology is also interested in people's reactions or responses to sound structures. Music can influence human functioning in multiple ways, impacting affect, thoughts and evaluations, body movement and physiological reactions (Schäfer, Sedlmeier, Städtler, \& Huron, 2013). In psychology, affect is understood as consciously accessible feelings that include long-lasting moods (e.g., cheerfulness, depression) and emotions (e.g., happiness, anger; Baas et al., 2008; Fredrickson, 2001). Musical affect can also include aesthetic judgments (Juslin, 2016). Whether music evokes genuine emotional responses in listeners or whether listeners merely perceive the emotions expressed by the music is an 
important issue in studies on music and emotion (Lundqvist, Carlsson, Hilmersson, \& Juslin, 2008).

\section{METHOD}

In our content analysis we examined the topics present in research on creating, practicing, and responding to music published in PoM from the inception of the journal until November 2019. The year of publication did not limit the search. We included studies with participants of both genders, of non-specific ethnicity, in all ages and involved all forms of music-based research. We used the SAGE database search engine to find studies of interest. Our search strategy is presented in Table 1. The terms used to find the studies were entered in four separate searches.

Table 1. Search Strategy Employed in Content Analysis

\begin{tabular}{lcl}
\hline \multicolumn{1}{c}{ Search terms } & Search field descriptor & Filter \\
\hline musical composition & All & research article \\
practice & Title & research article \\
reactions AND music & Title & research article \\
responses AND music & Title & research article \\
\hline
\end{tabular}

We found 531 article titles and abstracts, and screened them for eligibility for inclusion in this review, deciding whether they concerned topics of interest or not (Figure 1). After the selection process, we retained 98 articles that elaborated on one of the topic of interest: creating, practicing, or responding to music (one article elaborated on two topics - creating and practicing; Love \& Barrett, 2018).

Next, we developed a codebook that covered specific topics studied in conjunction with music creating, practicing, and responding to music. The remaining 98 articles were coded by these topics. Written descriptions of study aims were taken from abstracts of articles, except the study aim from one article which was obtained as a full text (as it did not have an abstract), in the case of two studies, descriptions were based on titles, due to the unavailability of abstracts or full text of these publications. 
Titles and abstracts screened in total: $n=\mathbf{5 3 1}$

musical composition: $n=450$

practice: $n=40$

reactions and music, responses and music: $n=41$

Figure 1. Flow chart presenting the process of study selection.

* The numbers across topic categories do not sum up to 98 as they contain one duplicate (item belonging to two categories).

\section{RESULTS}

Topics of Studies on Creating, Practicing, and Responding to Music

The first question was: "What are the topics of studies on creating, practicing, and responding to music published in PoM?" Based on our analysis of the journal's contents, we identified 17 topic areas, including six topics for creativity research, seven for practice research, and four for research on responses to music (Table 2). 
Table 2. Content Analysis Codebook

\begin{tabular}{|c|c|c|}
\hline $\begin{array}{l}\text { Research } \\
\text { area }\end{array}$ & Topic code and discourse & Description \\
\hline \multirow[t]{6}{*}{$\begin{array}{l}\text { Music } \\
\text { creating }\end{array}$} & $\begin{array}{l}\text { PMC - Predictors of } \\
\text { musical creativity }\end{array}$ & $\begin{array}{l}\text { These articles include research on factors that influence or } \\
\text { correlate with musical creativity. }\end{array}$ \\
\hline & $\begin{array}{l}\text { UPMC - Understanding } \\
\text { the process of music } \\
\text { creation }\end{array}$ & $\begin{array}{l}\text { These articles include research on people's behaviors, reac- } \\
\text { tions and thoughts during the music creation process. }\end{array}$ \\
\hline & $\begin{array}{l}\text { UMC - Utility of musical } \\
\text { creativity }\end{array}$ & $\begin{array}{l}\text { These articles include research presenting the role of music } \\
\text { creativity and the ways in which it can be profitable for } \\
\text { people. }\end{array}$ \\
\hline & $\begin{array}{l}\text { TLMC - Teaching and } \\
\text { learning musical composi- } \\
\text { tion }\end{array}$ & $\begin{array}{l}\text { These articles include research on the nature of teaching and } \\
\text { learning beliefs, processes and practices and on the nature of } \\
\text { interactions between a composer-teacher and a student- } \\
\text { composer. }\end{array}$ \\
\hline & $\begin{array}{l}\text { CMC - Collaborative } \\
\text { musical creativity }\end{array}$ & $\begin{array}{l}\text { These articles include research on collaborative musical } \\
\text { creativity and composition, for example during jam sessions. }\end{array}$ \\
\hline & $\begin{array}{l}\text { EMC - Evaluation of } \\
\text { musical creativity }\end{array}$ & $\begin{array}{l}\text { These articles include research on the evaluation of the results } \\
\text { of musical creativity, for example assessments of the original- } \\
\text { ity or quality of compositions. }\end{array}$ \\
\hline \multirow[t]{7}{*}{$\begin{array}{l}\text { Musical } \\
\text { practice }\end{array}$} & $\begin{array}{l}\text { DDP - Demographic } \\
\text { determinants of practice }\end{array}$ & $\begin{array}{l}\text { These articles include research exploring how different groups } \\
\text { of musicians, such as jazz or classical musicians, males or } \\
\text { females, differ in their musical practice. }\end{array}$ \\
\hline & $\begin{array}{l}\text { SRL - Self-regulated } \\
\text { music learning }\end{array}$ & $\begin{array}{l}\text { These articles include research on self-regulated learning in } \\
\text { musical practice. }\end{array}$ \\
\hline & $\begin{array}{l}\text { SDG - Self-determination } \\
\text { and goals in musical } \\
\text { practice }\end{array}$ & $\begin{array}{l}\text { These articles include research applying self-determination } \\
\text { theory or goal concept in the context of musical practice. }\end{array}$ \\
\hline & $\begin{array}{l}\text { OFP - Other factors } \\
\text { related to practice }\end{array}$ & $\begin{array}{l}\text { These articles include research on factors influencing musical } \\
\text { practice that did not fit into the DDP, SRL, or SDG categories. }\end{array}$ \\
\hline & $\begin{array}{l}\text { PIC - Practicing improvi- } \\
\text { sation and composition }\end{array}$ & $\begin{array}{l}\text { These articles include research on practice aimed at acquiring } \\
\text { skills in improvisation and composition. }\end{array}$ \\
\hline & $\begin{array}{l}\text { PAP - Practicing absolute } \\
\text { pitch }\end{array}$ & $\begin{array}{l}\text { These articles include research on practice aimed at the devel- } \\
\text { opment of absolute pitch. }\end{array}$ \\
\hline & $\begin{array}{l}\text { EMP - Effects of musical } \\
\text { practice }\end{array}$ & $\begin{array}{l}\text { These articles include research on the effects of musical } \\
\text { practice in terms of improvement in musical achievement. }\end{array}$ \\
\hline \multirow[t]{4}{*}{$\begin{array}{l}\text { Responses to } \\
\text { music }\end{array}$} & $\begin{array}{l}\text { ARM - Affective respons- } \\
\text { es to music }\end{array}$ & $\begin{array}{l}\text { These articles include research on affective responses to music } \\
\text { listening. }\end{array}$ \\
\hline & $\begin{array}{l}\text { BRM - Bodily responses } \\
\text { to music }\end{array}$ & These articles include research on bodily responses to music. \\
\hline & $\begin{array}{l}\text { PRM - Perceptual re- } \\
\text { sponses to music }\end{array}$ & $\begin{array}{l}\text { These articles include research on participants' ability to } \\
\text { describe the properties of music, i.e., to identify the musical } \\
\text { structure, and their awareness of details in music. }\end{array}$ \\
\hline & $\begin{array}{l}\text { ORM - Other responses } \\
\text { to music }\end{array}$ & $\begin{array}{l}\text { These articles include research on other types of responses to } \\
\text { music. }\end{array}$ \\
\hline
\end{tabular}


The second question was: "Which study topics were published the most often in PoM?" Some articles related to more than one category, rendering totals higher than 98. The majority of studies on musical creativity concerned PMC (Tables 2 and 3). Out of seven categories in practice research, studies on SRL and EMP were in the majority. Research on responses to music mainly explored the topics of ARM and BRM.

Table 3. Frequency and Percentage of Topics in Studies on Creating, Practicing, and Responding to Music Published in PoM

\begin{tabular}{|c|c|c|c|}
\hline Area of research & Topics & $N$ & $\%$ \\
\hline \multirow{6}{*}{ Music creating } & Predictors of musical creativity & 9 & 25.00 \\
\hline & Understanding the process of music making & 6 & 16.67 \\
\hline & Utility of musical creativity & 5 & 13.89 \\
\hline & Teaching and learning musical composition & 4 & 11.11 \\
\hline & Collaborative creativity & 6 & 16.67 \\
\hline & Evaluation of musical creativity & 6 & 16.67 \\
\hline \multirow{7}{*}{ Musical practice } & Demographic determinants of practice & 5 & 12.20 \\
\hline & Self-regulated music learning & 11 & 26.83 \\
\hline & Self-determination and goals in musical practice & 6 & 14.63 \\
\hline & Other factors influencing practice & 4 & 9.76 \\
\hline & Practicing improvisation and composition & 3 & 7.32 \\
\hline & Practicing absolute pitch & 2 & 4.88 \\
\hline & Effects of musical practice & 10 & 24.39 \\
\hline \multirow{4}{*}{ Responses to music } & Affective responses & 23 & 53.49 \\
\hline & Bodily responses & 10 & 23.26 \\
\hline & Perceptual responses & 8 & 18.60 \\
\hline & Other responses & 2 & 4.65 \\
\hline
\end{tabular}

The third question was: "What are the major aims of studies addressing each topic?" In the following sections we describe the aims of studies on creativity, practice, and responses to music that were included in this analysis. 


\section{Research on Creativity}

Nine studies on the PMC aimed to explain musical creativity or music making by studying factors that could influence them. Mawang, Kigen, and Mutweleli (2018) studied the relationships between goal achievement motivation, cognitive learning strategies, and musical creativity. MacIntyre and Potter (2013) tested motivational differences (i.e., musical self-esteem, effort, desire to learn, willingness to play, and possible musical selves) between those who wrote music, those who planned to write music in the future, and those who did not write nor intend to write music. Another study (MacDonald, Byrne, \& Carlton, 2016) explored the relation between self-assessed creativity, flow (i.e., optimal experience from Csikszentmihalyi's theory), and the quality of the compositions.

Beyond motivational variables, researchers (Sovansky, Wieth, Francis \& McIlhagga, 2014) also investigated how the level of music expertise and engagement in music creation were related to increased creativity. Similarly, Seddon and O'Neill $(2001,2006)$ studied the role of composers' experience of formal instrumental music tuition in the quality of compositions, while Colley, Banton, Down, and Pither (1992) compared the strategies employed in expert and novice performances of composition task.

Some behaviors can also have an impact on music making. Eskine, Anderson, Sullivan, and Golob (2018) examined whether the effect of music listening on semantic memory and/or mood are mechanisms responsible for creativity. Hill, Hill, and Walsh (2017) studied the impact of task-based and interpersonal conflicts between band members on the creation of collaborative compositions.

Six studies concerning UPMC presented the characteristics of the music making process, exploring people's behaviors, reactions, and thoughts during creation. For example, Collins (2005) mapped cognitive processes during the compositional process tracked in real time. Burnard (1999) focused on children' kinesthetic memory in improvisation and composition tasks, while Dean and Bailes (2015) explored skin conductance in musicians during piano improvisation. Investigating flow (MacDonald et al., 2016) or verbal and nonverbal interactions (Hill et al., 2017) during the composition process constituted other aims of research on UPMC. Lastly, Williams et al. (2014) reviewed studies implementing systems for algorithmic composition with the intention of targeting specific emotional responses in the listener.

Five studies on UMC show how musical creativity can be profitable for people; for example it can be used for psychotherapeutic purposes. Allen (2013) examined the effectiveness of free improvisation as a treatment for the reduction 
of performance anxiety, while Baker (2013) investigated music therapists' perceptions of the role of music in the therapeutic songwriting process. Another project investigated the role of invented song-making and music engagement in young child identity development (Barrett, 2010). Goncy and Waehler (2006) examined the correlational relationship between self-reported creative personality traits and self-reported musical experience. Lastly, Perkins and Williamon (2013) aimed to demonstrate that learning composition in older adulthood offered significant wellbeing benefits, enhancing health-promoting behaviors.

Four studies addressed the topic of TLMC. Barrett (2006) investigated the teaching and learning beliefs, processes, and practices of a composer-teacher when working with a student-composer over the course of one academic semester. Barrett and Gromko (2007) videotaped formal interactions between a composer-teacher and a student-composer and interviewed them individually. Love and Barrett $(2015,2018)$ examined practices and structures evidenced through a composers' workshop via observation of rehearsals, masterclasses, and interviews with students, teachers, and a conductor.

Six studies investigated CMC. Hart and Di Blasi (2013) explored the subjective experience of combined flow in musical jam sessions. Flow experience during the group compositional process was also examined in the study by MacDonald et al. (2016). Another, previously mentioned, study showed the impact of interpersonal conflicts on collaborative compositions (Hill et al., 2017). Wilson and MacDonald (2012) compared interview data collected from jazz musicians' and free improvisers' from varied backgrounds, exploring the differences in the way group improvisation was constructed. Hass, Weisberg, and Choi (2010) aimed to examine the career development of collaborative songwriting teams. Finally, Sawyer (2006) presented three defining characteristics of group creativity: improvisation, collaboration, and emergence, presenting several examples of group creativity in both music and theater.

Six studies focused on EMC. Kozbelt (2007) presented an analysis of Ludwig van Beethoven self-critical statements about his compositions, found in his letters and conversations. Another example is the study by MacDonald et al. (2016) in which compositions completed by participants were recorded and rated for quality and creativity by the participants and by a group of music education specialists. In a different study (Priest, 2006) the relation between self-assessment of students' compositions and independent judges' assessments was investigated. Seddon and O'Neill evaluated computer-based compositions prepared by children (2001) and adolescents (2006). Evaluations were made by music specialist and nonspecialist teachers, the children themselves, and experts. 
Lastly, Simonton (1994) described the computerized content analysis of musical structure, which enabled the assessment of a composition's originality.

To sum up, studies on PMC mostly focused on the level of musical experience as a predictor ( $n$ of studies $=4$ ), motivational variables were the second studied type of predictors $(n=3)$, and single studies investigated the influence of music listening or conflicts among compositors on musical creativity. Among studies concerning UPMC, single studies explored skin conductance, kinesthetic memory, cognitive processes, flow, or social interaction during music creating. UMC research explored the usefulness of music creativity in therapy $(n=2)$ and in enhancing the psychological functioning of children $(n=1)$ and adults $(n=1)$, and presented the link between creativity and musical experience $(n=1)$. TLMC studies investigated the processes taking place during a composition course $(n=2)$ or compositional workshop $(n=2)$. Studies on CMC referred to flow $(n=2)$, and single studies investigated communication, career development, the role of musical genre background, or the definitions of terms related to collaborative creativity. Studies on EMC mostly concerned human assessment $(n=5)$; one study evaluated computer evaluations of compositions.

\section{Research on Practice}

There were five studies on DDP. Hallam et al. (2016) studied gender differences in the amount of practice, practice strategies, and motivation among children and adolescents. Hallam et al. also investigated how the level of musicians' expertise (2012) or the instrument played (Hallam, Creech, Varvarigou, \& Papageorgi, 2019) influenced the strategies and motivation to practice. Sandgren (2018) focused on the differences in instrumental practice across musicians representing various musical genres (jazz, folk music, classical) and vocalists in relation to instrumentalists. Lastly, Austin and Berg (2006) compared band and orchestra students' practice motivation, frequency of practice, amount of practice, and practice regulation.

Eleven studies addressed the topic of SRL. Four of them aimed to develop or adapt a measure of self-regulated practice (Araújo, 2015; Ersozlu \& Miksza, 2014; Madeira, Araújo, Hein, \& Marinho, 2017; McPherson, Osborne, Evans, \& Miksza, 2017). Pike (2017) analyzed practice strategies applied by piano students, Austin and Berg (2006) examined the practice motivation and regulation of band and orchestra students, while Nielsen (1999) explored the use of learning strategies by one church organ student. Later, Nielsen (2004) studied the learning strategies of advanced music students and their relation to self-efficacy. Similar- 
ly, Miksza (2013) verified the effect of SRL instruction on wind players' performance achievement, practice behavior, and self-efficacy. Bonneville-Roussy and Bouffard (2015) aimed to test an integrative framework in which self-regulation, deliberate practice strategies, and practice time were simultaneously taken into account in the prediction of musical achievement. Boucher, Creech and Dubé (2019) focused on one specific SRL strategy, namely video feedback, and analyzed its influence on the self-evaluation of guitarists while practicing a new piece of music.

Six studies on SDG used either self-determination theory or goal concept in exploring practice. Evans and Bonneville-Roussy (2016) investigated whether needs fulfilment and autonomous motivation of university music students explained context-specific affect and practice behavior. A different study investigated the influence of autonomy and competence needs satisfaction on flow experience in instrumental practice (Valenzuela, Codina, \& Pestana, 2017). Schatt (2017) examined factors influencing self-determination for practice and validated an instrument to measure self-determination in practice. Chaffin and Imreh (2001) focused on the goals of expert practice and how they changed across the learning process. In another study (Smith, 2005), the author examined how goal orientation and implicit theory of ability were related to practice behavior, and evaluated the adaptation of measures of academic motivation to the musical domain. Similarly, Miksza (2010) studied the relationships between achievement goal motivation, music performance, impulsivity, and music practice.

Four studies concerned OFP. Barry and McArthur (1994) evaluated an inventory designed to assess the extent to which studio music teachers taught certain practice strategies. Ginsborg, Chaffin, and Nicholson (2006) reported a content analysis of musicians' (a singer and pianist/conductor's) verbal commentaries made in individual practice sessions and their discussions during joint rehearsals. The third study summarized the literature concerning the relationship between affect and instrumental practice (Mazur \& Laguna, 2019). The fourth study tested whether perceptual learning style theory applied to the learning of musical material (Odendaal, 2015).

There were three studies on PIC. Kanellopoulos (1999) investigated children's idea of musical improvisation in their practice of spontaneous music making, using an ethnographic, open-ended process of gathering data. Johansen (2017) analyzed empirical data from a qualitative study on jazz students' instrumental practice and discussed approaches to instrumental practice that served the purpose of developing improvisation competence. Love and Barrett (2018) 
studied how music composition students acquired their skills during practice in a workshop with composition teachers.

Two studies focused on PAP. Crozier (1997) aimed to verify whether there was a critical period in the development of absolute pitch and whether the same techniques for acquiring absolute pitch were more effective with immature compared to mature individuals. Sakakibara (2012) performed a longitudinal study to investigate the process of acquiring absolute pitch in young children.

We found ten studies that measured EMP. Four previously mentioned studies (Bonneville-Roussy, \& Bouffard, 2015; Boucher et al., 2019; Miksza, 2010, 2013) investigated the links between SRL and performance achievement. Also, Allen (2012) studied procedural memory consolidation effects on performance. Barry (1992) assessed the effects of field-dependence/independence and gender upon the technical accuracy and musicality of student instrumental performance under both structured and free practice conditions. Evans and McPherson (2014) report on their longitudinal study of children's musical identity, their instrumental practice, and subsequent achievement and motivation for playing music. Hallam, Papageorgi, Varvarigou, and Creech (2018) examined how self-reported instrumental practice and motivation to learn were related to instrumental examination outcomes. Rosemann, Altenmüller, and Fahle (2015) investigated the impact of practice, playing tempo and the complexity of the music on the size of the eye-hand span (the distance between eye - fixation of note, and hand position tapping the corresponding key), and its relation to the quality of performance after practice. The last study examined the effects of cognitive load during practice on the effects of university wind students' learning (Stambaugh, 2012).

To sum up, single studies on DDP presented the role of gender, musical expertise, instrument played, musical genre or type of musical training in instrumental practice. Single studies on OFP investigated teaching strategies, learning style, affect, or communication in the context of instrumental learning. Studies on SRL concerned measurement tools $(n=4)$ and investigated practice strategies used by musicians $(n=3)$ or the link between practice behaviors and self-efficacy and/or the effects of practice $(n=4)$. Research on SDG referred to the theory of self-determination $(n=3)$ or to the concept of goal $(n=3)$. Studies on other types of practice (PIC and PAP) focused on learning improvisation $(n=2)$, composition $(n=1)$, or absolute pitch $(n=2)$. Lastly, EMP studies linked SRL with musical achievements $(n=4)$ and considered tempo or cognitive load during practice $(n=2)$; single studies presented the effects of memory consolidation, motivation, gender, and field-dependence on children's musical identity. 


\section{Research on Responses to Music}

Twenty three studies explored ARM. Four of them described measurement tools for the investigation of affective reactions (Asmus, 1985; De Vries, 1991; Sandstrom \& Russo, 2011; Yinger \& Springer, 2018). Music may arouse various emotions in listeners, and 14 studies were devoted to the circumstances that contribute to such affective reactions. Krahé, Hahn, and Whitney (2015) explored which channel of information-visual (body movements) or auditory (musical material) - determined the emotions perceived and felt in response to music performance. In a similar way, Gfeller, Asmus, and Eckert (1991) compared the effects of musical and textual settings (text alone, commercial-type background music, commercial-type background music with text, atonal music, atonal music with text) on the listeners' affective response and mood.

People's emotional responses can also depend on the music they listen to. Imbir and Gołąb (2017) assessed the affective connotations of musical excerpts covering both modern musical genres and classical music. Daynes (2010) focused on the role of the familiarity and the tonal or atonal character of music in predicting the emotional reactions experienced by listeners. Holbrook and Anand (1990) investigated the effects of tempo and situational arousal on the listeners' perceptual and affective responses to music. Sloboda (1991) explored which features of musical structure (e.g., passages containing sequences) was responsible for the occurrence of a range of physical reactions while listening to music (e.g., laughter, tears). Saiz-Clar and Reales (2017) developed a composite neural network that predicted activation and emotional valence from a set of temporal and tonal properties of the stimuli (e.g., rhythm, tempo) and classified the stimuli into four emotional categories (calm, happiness, fear, and sadness). Luck et al. (2007) explored the relationships between musical features relating to various aspects of music therapy improvisations (e.g., timing, dynamics, tonality) and participants' emotion ratings of that music.

Affective responses to music can be culture-specific. Gregory and Varney (1996) presented cross-cultural comparisons between European and Asian subjects in affective response to a variety of excerpts of Western classical, Indian classical, and New Age music. Cultural aspect of affective responses was also explored in the study by Susino and Schubert (2018). They verified whether emotional responses to a music genre could be predicted by the stereotypes of the culture that the music genre was associated with.

Not only the features of music and the environment, but also the features and decisions of the people who listen to music can impact their emotional reactions 
to sound stimuli. In their experimental study, Liljeström, Juslin, and Västfjäll (2012) examined the roles of music choice, social context, and listener personality in emotional reactions to music (i.e., self-reported emotions, skin conductance, heart rate). Rawlings and Leow (2008) examined the role of psychoticism and sensation seeking, while Lehmann (1997) assessed the influence of the listener's formal music training on affective responses to music listening. Another study (Sakka \& Juslin, 2017) investigated whether listeners showed different patterns of emotional reactions to music depending on the level of depression. Gupta and Gupta (2014) compared the psychophysiological responses to music-listening (i.e., blood pressure, heart rate, self-reported affect) in male coronary patients and healthy controls.

Lundqvist et al. (2008) aimed to distinguish, whether music evoked genuine emotional responses in listeners or whether listeners merely perceived emotions expressed by the music. They measured self-reported emotion, facial muscle activity, and autonomic activity in music listeners. Correspondence between emotion components was also investigated by Rickard (2004), who explored whether music which elicited intense subjective emotions produced higher levels of physiological arousal than less emotionally powerful music. Lastly, Waterman (1996) focused on explicit and implicit response effects when listening to or performing music. In contrast to authors exploring genuine responses, Hargreaves and Colman (1981) explored the frequency of affective responses that are subjective and evaluative (e.g., "cheerful," "weird," "horrible").

Ten studies explored listeners' BRM. Six of these refer to body reactions accompanying ARM, and have been mentioned above (De Vries, 1991; Gupta \& Gupta, 2014; Liljeström et al., 2012; Lundqvist et al., 2008; Rickard, 2004; SaizClar \& Reales, 2017). Caravaglios et al. (2019) explored differences in cognitive functioning between people with and without musical training, as measured by electroencephalographic (EEG) and behavioral responses during an experimental task tapping into attention and monitoring mechanisms. Brain responses evoked by music were also investigated by Wen and Tsai (2016). These authors recorded cortical activity, examining how the auditory-evoked magnetic fields were affected by harmonizing music of rapidly changing tonalities. Sims (1988) evaluated movement responses to characteristics of musical phrases. Subjects individually performed a movement activity designed to elicit reactions to the varying phrase structures and stylistic characteristics of the music. Finally, Fachner (2014) reported research on the music effects on neural processing in brain regions that are implicated in music, language, and emotion processing. 
Eight studies measured PRM. Daynes (2010) and Holbrook and Anand (1990), mentioned earlier, went beyond emotional responses and investigated also perceptual responses to music (e.g., awareness of details of music, perceived activity). Fredrickson (1995) used the Continuous Response Digital Interface $(\mathrm{CRDI})^{3}$ to measure musicians' and non-musicians' perceptions of ongoing "aesthetic" response, in an attempt to determine if musical "tension" was related to the aesthetic experience. Durkin and Townsend (1997) studied responses to musical pitch tests, and Block (1983) examined tone-color responses of musicians with absolute pitch or good relative pitch. Before mentioned, Hargreaves and Colman (1981), proposed four other categories of response to music, beyond affective, namely: categorical (classifies music as representing a particular style, e.g., folk, pop, classical), objective-analytic (refers to "technical" elements, e.g., tempo or instrumentation), objective-global (refers to qualities of the music as a whole e.g., "religious," "twentieth century"), and associative (extra-musical associations, e.g., "birds singing," "the sea"), and explored how frequently each of these categories was used when people described musical extracts. The remaining two articles dealt with "musical cognition and aesthetic response" (Swanwick, 1973) and "verbal and exploratory responses to melodic musical intervals" (Maher \& Berlyne, 1982) ${ }^{4}$.

Two studies explored ORM. Beyond physiological and affective responses, Gupta and Gupta (2014) also explored changes in life satisfaction, optimism, and hope due to exposure to music. Bennett and Ginsborg (2018) studied the effect of providing program notes of unfamiliar music on the listeners' reactions during musical performance (reactions to music are understood in a more general way).

To sum up, with regard to ARM, studies explored the role of music characteristics $(n=6)$, the role of individual features such as personality, musical training, or health $(n=5)$, culture $(n=2)$, or channel of information processing $(n=1)$. Studies on BRM investigated body responses in ARM $(n=6)$, referred to the brain activity $(n=3)$ or body movements $(n=1)$. PRM research focused on to the ability to recognize music structure, pitch or tone-color responses $(n=4)$, perceived aesthetic responses $(n=2)$, perceived activity $(n=1)$, or categorical, objective and associative responses to music $(n=1)$. ORM studies explored changes in personal characteristics $(n=1)$ and general responses to music $(n=1)$.

\footnotetext{
3 This device gives listeners an opportunity to respond non-verbally while music is being played.

${ }^{4}$ Due to the lack of access to the full texts of these last two publications, we only cite their titles here.
} 


\section{DISCUSSION}

This content analysis was performed in order to identify and describe the themes in research on creating, practicing, and responding to music published in $P o M$. Searching for research on responses to music yielded the largest number of relevant studies, and searching for research on music creating revealed the smallest number of relevant studies. We proposed to organize the literature into 17 topics. The largest number of studies investigate PMC, SRL, EMP, ARM, and BRM.

Based on this review, it is possible to suggest some areas that may need further attention in research. The aims of studies on PMC showed that researchers investigated the role of experience, motivation, and behavior. However, the list of music making predictors presented in this review is not exhaustive. For example, although many theories show that mood has an influence on creative thinking (Baas et al., 2008), affect was not taken into account as a determinant of music making in the studies included in this review, except in one study (Eskine et al., 2018). ${ }^{5}$ Also the environment can determine the opportunities to engage in music making, as some cultures do not value musical composition while in others creating music is highly important for society (Hallam et al., 2018). From the analysis of research on practice, it appears that formal instrumental practice is the most commonly studied phenomenon, while other learning activities, such as practicing improvisation or the ability to recognize sounds, are rarely explored. In case of responses to music, research has mainly focused on ARM, BRM, and PRM, and there has been only one study on personal characteristics change. Future studies may fill these research gaps.

The results of the research mentioned in this review can be applied for practical purposes in music psychology. A large body of research on affective responses to music can inform music therapy, and research on SRL and its effects on musical achievement can be taken into account in the management of teaching and learning strategies, helping psychologists and teachers to improve the quality of their work with musicians. Our comprehensive review of musical creativity research can also be considered an important source of knowledge for people who create music themselves or who are responsible for providing others with opportunities to learn musical composition or improvisation.

Given the constrains of this analysis, however, the list of topic categories that we have developed, as well as the description of these categories, is not perfect

\footnotetext{
${ }^{5}$ Also, the experience of flow, which is regarded as an "exhilarating feeling" was measured in two studies, but only in the context of collaborative composition process.
} 
and may not fully reflect the contents of the journal. Our analysis had a very broad scope; we therefore searched the literature on practice and responses to music based on article titles only, as it would be difficult to manage and describe more research items in a single review article. As, for example, the titles of some studies on musical practice may not contain the word "practice," there is a risk that we omitted some papers about the selected topics published in PoM. It is therefore not possible to say whether the differences between the number of studies on music creating, performing, and responding (e.g., the smallest number of research on music creating) reflect the actual differences in researchers' interests or whether they are caused by the weakness in our search methods. Also, this article covers the contents of one of the key journals in the domain of music psychology, and there arises the question of the generalizability of its findings.

Future research can apply a more systematic approach to the literature review (Booth, Sutton, \& Papaioannou, 2012), utilizing more focused research questions, refined search methods (e.g., the use of synonymous search terms; the inclusion of other journals and databases). In subsequent reviews we propose to present information on study characteristics, the characteristics of the study samples, measurement tool(s), the description of the intervention, and the results. Having such data, researchers can spot specific gaps in research and future studies to fill them. Although in this article we have presented only a simple analysis of the topics included in PoM, the results of our analysis and those of future review studies can help to integrate and summarize the available knowledge, enabling the strategic planning of new research as well as informing psychological and educational practice.

\section{CONCLUSION AND ISSUE CONTENT}

By referring to the concepts of "creating," "practicing," and "reacting" to music, we set the scene for further psychological explorations in Poland and thus announce the next thematic issue of $A o P$. So far, this journal has rarely referred to the psychology of music (Iskra, 1998; Hekiert \& Igras-Cybulska, 2019). However, lately $A o P$ published an issue entirely devoted to the field of music psychology, more specifically to psychological reactions to movie music (Chełkowska-Zacharewicz \& Paliga, 2019), the perception of musical structure (Podlipniak, 2019), music therapy for preterm infants and their parents (Bieleninik \& Ghetti, 2019), and musicians' study addiction and examination stress (Atroszko, Wróbel, Bereznowski, \& Lawendowski, 2019). 
The current issue of $A o P$ adds to the previous work, helping to understand the measurement of affect induced by music, the psychological functioning of musicians, and the way they create and practice. The issue begins with a review on theories explaining musical idea generation by Natalia Copeland (2019). Next, there is the study on jazz and classical musicians' coping skills by Anna Nogaj and colleagues (2019), followed by Stella Kaczmarek's (2019) study on teenagers' mental practice. The last article, by Maciej Janowski and Maria Chełkowska-Zacharewicz (2019), presents a review of studies on music-induced affect, exploring, whether these studies measure real (basic) emotions, or rather affect or music emotions.

The papers included in this special issue cover a wide range of topics related to "creating, practicing, and reacting to music," providing important information on the person-music relationship. Due to its intricate and complex nature, it is recommended to conduct further research analyses in this area, in line with the aim of $P o M$, which is to "increase the scientific understanding of all psychological aspects of music and music education."

\section{REFERENCES ${ }^{6}$}

*Allen, R. (2013). Free improvisation and performance anxiety among piano students. Psychology of Music, 41(1), 75-88. https://doi.org/10.1177/0305735611415750

*Allen, S. E. (2012). Memory stabilization and enhancement following music practice. Psychology of Music, 41(6), 794-803. https://doi.org/10.1177/0305735612463947

*Araújo, M. V. (2015). Measuring self-regulated practice behaviours in highly skilled musicians. Psychology of Music, 44(2), 278-292. https://doi.org/10.1177/0305735614567554

*Asmus, E. P. (1985). The development of a multidimensional instrument for the measurement of affective responses to music. Psychology of Music, 13(1), 19-30. https://doi.org/10.1177/ 0305735685131002

Atroszko, P. A., Wróbel, W. K., Bereznowski, P., \& Lawendowski, R. (2019). The relationship between study addiction and examination stress among students of music academies. Roczniki Psychologiczne [Annals of Psychology], 22(2), 177-192. https://doi: 10.18290/rpsych.2019.22.2-5

*Austin, J. R., \& Berg, M. H. (2006). Exploring music practice among sixth-grade band and orchestra students. Psychology of Music, 34(4), 535-558. https://doi.org/10.1177/030573560 6067170

Baas, M., De Dreu, C. K. W., \& Nijstad, B. A. (2008). A meta-analysis of 25 years of moodcreativity research: Hedonic tone, activation, or regulatory focus? Psychological Bulletin, 134(6), 779-806. https://doi.org/10.1037/a0012815

*Baker, F. A. (2013). What about the music? Music therapists' perspectives on the role of music in the therapeutic songwriting process. Psychology of Music, 43(1), 122-139. https://doi.org/ $10.1177 / 0305735613498919$

\footnotetext{
${ }^{6}$ Publications included in the review are marked with an asterisk $(*)$.
} 
*Barrett, M. (2006). 'Creative collaboration': An 'eminence' study of teaching and learning in music composition. Psychology of Music, 34(2), 195-218. https://doi.org/10.1177/030573560 6061852

*Barrett, M. S. (2010). Musical narratives: A study of a young child's identity work in and through music-making. Psychology of Music, 39(4), 403-423. https://doi.org/10.1177/030573561037 3054

*Barrett, M. S., \& Gromko, J. E. (2007). Provoking the muse: A case study of teaching and learning in music composition. Psychology of Music, 35(2), 213-230. https://doi.org/ $10.1177 / 0305735607070305$

*Barry, N. H. (1992). The effects of practice strategies, individual differences in cognitive style, and gender upon technical accuracy and musicality of student instrumental performance. Psychology of Music, 20(2), 112-123. https://doi.org/10.1177/0305735692202002

*Barry, N. H., \& McArthur, V. (1994). Teaching practice strategies in the music studio: A survey of applied music teachers. Psychology of Music, 22(1), 44-55. https://doi.org/10.1177/030573 5694221004

*Bennett, D., \& Ginsborg, J. (2018). Audience reactions to the program notes of unfamiliar music. Psychology of Music, 46(4), 588-605. https://doi.org/10.1177/0305735617721339

Bieleninik, Ł., \& Ghetti, C. M. (2019). Music therapy for preterm infants and their parents: A path forward for research in Poland. Roczniki Psychologiczne [Annals of Psychology], 22(2), 135150. https://doi.org/10.18290/rpsych.2019.22.2-3

*Block, L. (1983). Comparative tone-colour responses of college music majors with absolute pitch and good relative pitch. Psychology of Music, 11(2), 59-66. https://doi.org/10.1177/03057 35683112001

*Bonneville-Roussy, A., \& Bouffard, T. (2015). When quantity is not enough: Disentangling the roles of practice time, self-regulation and deliberate practice in musical achievement. Psychology of Music, 43(5), 687-704. https://doi.org/10.1177/0305735614534910

Booth, A., Sutton, A., \& Papaioannou, D. (2012). Systematic approaches to a successful literature review. London, UK: Sage.

*Boucher, M., Creech, A., \& Dubé, F. (2019). Video feedback and the self-evaluation of collegelevel guitarists during individual practice. Psychology of Music. https://doi.org/10.1177/ 0305735619842374

*Burnard, P. (1999). Bodily intention in children's improvisation and composition. Psychology of Music, 27(2), 159-174. https://doi.org/10.1177/0305735699272007

*Caravaglios, G., Castro, G., Crivelli, D., De Filippis, D., Muscoso, E. G., Di Maria, G., ... Balconi, M. (2019). Musical expertise: Evidence from a pilot study on reaction times and time/frequency oscillatory responses. Psychology of Music. Advanced online publication. https://doi.org/10.1177/0305735619839141

*Chaffin, R., \& Imreh, G. (2001). A comparison of practice and self-report as sources of information about the goals of expert practice. Psychology of Music, 29(1), 39-69. https://doi.org/10.1177/0305735601291004

Chełkowska-Zacharewicz, M., \& Paliga, M. (2019). Music emotions and associations in film music listening: An example of leitmotifs from The Lord of the Rings movies. Roczniki Psychologiczne [Annals of Psychology], 22(2), 151-175. https://doi.org/10.18290/ rpsych.2019.22.2-4

*Colley, A., Banton, L., Down, J., \& Pither, A. (1992). An expert-novice comparison in musical composition. Psychology of Music, 20(2), 124-137. https://doi.org/10.1177/0305735692202003 
*Collins, D. (2005). A synthesis process model of creative thinking in music composition. Psychology of Music, 33(2), 193-216. https://doi.org/10.1177/0305735605050651

Copeland, N. (2019). Spontaneous creativity: An overview of theories crucial to musical idea generation. Roczniki Psychologiczne [Annals of Psychology], 22(4), 325-336. http://dx.doi. org/10.18290/rpsych.2019.22.4-2

*Crozier, J. B. (1997). Absolute pitch: Practice makes perfect, the earlier the better. Psychology of Music, 25(2), 110-119. https://doi.org/10.1177/0305735697252002

*Daynes, H. (2010). Listeners' perceptual and emotional responses to tonal and atonal music. Psychology of Music, 39(4), 468-502. https://doi.org/10.1177/0305735610378182

*De Vries, B. (1991). Assessment of the affective response to music with Clynes's sentograph. Psychology of Music, 19(1), 46-64. https://doi.org/10.1177/0305735691191004

*Dean, R. T., \& Bailes, F. (2015). Using time series analysis to evaluate skin conductance during movement in piano improvisation. Psychology of Music, 43(1), 3-23. https://doi.org/10.1177/ 0305735613489917

*Durkin, K., \& Townsend, J. (1997). Influence of linguistic factors on young school children's responses to musical pitch tests: A preliminary test. Psychology of Music, 25(2), 186-191. https://doi.org/10.1177/0305735697252007

Ericsson, K., Krampe, R., \& Tesch-Roemer, C. (1993). The role of deliberate practice in the acquisition of expert performance. Psychological Review, 100(3), 363-406.

*Ersozlu, Z. N., \& Miksza, P. (2014). A Turkish adaptation of a Self-Regulated Practice Behavior Scale for collegiate music students. Psychology of Music, 43(6), 855-869. https://doi.org/ $10.1177 / 0305735614543283$

*Eskine, K. E., Anderson, A. E., Sullivan, M., \& Golob, E. J. (2018). Effects of music listening on creative cognition and semantic memory retrieval. Psychology of Music. Advanced online publication. https://doi.org/10.1177/0305735618810792

*Evans, P., \& Bonneville-Roussy, A. (2016). Self-determined motivation for practice in university music students. Psychology of Music, 44(5), 1095-1110. https://doi.org/10.1177/030573 5615610926

*Evans, P., \& McPherson, G. E. (2014). Identity and practice: The motivational benefits of a longterm musical identity. Psychology of Music, 43(3), 407-422. https://doi.org/10.1177/0305 735613514471

*Fachner, J. (2014). Communicating change-meaningful moments, situated cognition and music therapy: A response to North (2014). Psychology of Music, 42(6), 791-799. https://doi.org/ $10.1177 / 0305735614547665$

Fredrickson, B. L. (2001). The role of positive emotions in positive psychology. The American Psychologist, 56(3), 218-226.

*Fredrickson, W. E. (1995). A comparison of perceived musical tension and aesthetic response. Psychology of Music, 23(1), 81-87. https://doi.org/10.1177/0305735695231006

*Gfeller, K., Asmus, E., \& Eckert, M. (1991). An investigation of emotional response to music and text. Psychology of Music, 19(2), 128-141. https://doi.org/10.1177/0305735691192004

*Ginsborg, J., Chaffin, R., \& Nicholson, G. (2006). Shared performance cues in singing and conducting: A content analysis of talk during practice. Psychology of Music, 34(2), 167-194. https://doi.org/10.1177/0305735606061851

*Goncy, E. A., \& Waehler, C. A. (2006). An empirical investigation of creativity and musical experience. Psychology of Music, 34(3), 307-321. https://doi.org/10.1177/0305735606064839 
*Gregory, A. H., \& Varney, N. (1996). Cross-cultural comparisons in the affective response to music. Psychology of Music, 24(1), 47-52. https://doi.org/10.1177/0305735696241005

*Gupta, U., \& Gupta, B. S. (2014). Psychophysiological reactions to music in male coronary patients and healthy controls. Psychology of Music, 43(5), 736-755. https://doi.org/ $10.1177 / 0305735614536754$

*Hallam, S., Rinta, T., Varvarigou, M., Creech, A., Papageorgi, I., Gomes, T., \& Lanipekun, J. (2012). The development of practising strategies in young people. Psychology of Music, 40(5), 652-680. https://doi.org/10.1177/0305735612443868

*Hallam, S., Creech, A., Varvarigou, M., \& Papageorgi, I. (2019). Are there differences in practice depending on the instrument played? Psychology of Music. Advanced online publication. https://doi.org/10.1177/0305735618816370

*Hallam, S., Papageorgi, I., Varvarigou, M., \& Creech, A. (2018). Relationships between practice, motivation, and examination outcomes. Psychology of Music. Advanced online publication. https://doi.org/10.1177/0305735618816168

*Hallam, S., Varvarigou, M., Creech, A., Papageorgi, I., Gomes, T., Lanipekun, J., \& Rinta, T. (2016). Are there gender differences in instrumental music practice? Psychology of Music, 45(1), 116-130. https://doi.org/10.1177/0305735616650994

*Hargreaves, D. J., \& Colman, A. M. (1981). The dimensions of aesthetic reactions to music. Psychology of Music, 9(1), 15-20. https://doi.org/10.1177/03057356810090010301

*Hart, E., \& Di Blasi, Z. (2013). Combined flow in musical jam sessions: A pilot qualitative study. Psychology of Music, 43(2), 275-290. https://doi.org/10.1177/0305735613502374

*Hass, R. W., Weisberg, R. W., \& Choi, J. (2010). Quantitative case-studies in musical composition: The development of creativity in popular-songwriting teams. Psychology of Music, 38(4), 463-479. https://doi.org/10.1177/0305735609352035

Hekiert, D., \& Igras-Cybulska, M. (2019). Capturing emotions in voice: A comparative analysis of methodologies in psychology and digital signal processing. Roczniki Psychologiczne [Annals of Psychology], 22(1), 15-34. https://doi.org/dx.doi.org/10.18290/rpsych.2019.22.1-2

*Hill, M., Hill, B., \& Walsh, R. (2017). Conflict in collaborative musical composition: A case study. Psychology of Music, 46(2), 192-207. https://doi.org/10.1177/0305735617704712

*Holbrook, M. B., \& Anand, P. (1990). Effects of tempo and situational arousal on the listener's perceptual and affective responses to music. Psychology of Music, 18(2), 150-162. https://doi.org/10.1177/0305735690182004

*Imbir, K., \& Gołąb, M. (2017). Affective reactions to music: Norms for 120 excerpts of modern and classical music. Psychology of Music, 45(3), 432-449. https://doi.org/10.1177/0305735 616671587

Iskra, J. (1998). Stopień otwartości na doświadczenie a obraz siebie młodzieży artystycznie uzdolnionej [Degree of openness to experience and self-image among artistically talented adolescents]. Roczniki Psychologiczne [Annals of Psychology], 1, 57-71.

Janowski, M., \& Chełkowska-Zacharewicz, M. (2019). What do we actually measure as music-induced emotions? Roczniki Psychologiczne [Annals of Psychology], 22(4), 373-403. http://dx.doi.org/10.18290/rpsych.2019.22.4-5

*Johansen, G. G. (2017). Explorational instrumental practice: An expansive approach to the development of improvisation competence. Psychology of Music, 46(1), 49-65. https://doi.org/10.1177/0305735617695657 
Juslin, P. N. (2016). Emotional reactions to music. In S Hallam, I. Cross, \& M. Thaut (Eds.), The Oxford handbook of music psychology (2nd ed., pp. 197-214). Oxford, UK: Oxford University Press.

Kaczmarek, S. (2019). Mental practice of musically gifted adolescents. Roczniki Psychologiczne [Annals of Psychology], 22(4), 353-372. http://dx.doi.org/10.18290/rpsych.2019.22.4-4

*Kanellopoulos, P. A. (1999). Children's conception and practice of musical improvisation. Psychology of Music, 27(2), 175-191. https://doi.org/10.1177/0305735699272008

Keller, P. E., Weber, A., \& Engel, A. (2011). Practice makes too perfect: Fluctuations in loudness indicate spontaneity in musical improvisation. Music Perception: An Interdisciplinary Journal, 29(1), 109-114. https://doi.org/10.1525/mp.2011.29.1.109

*Kozbelt, A. (2007). A quantitative analysis of Beethoven as self-critic: Implications for psychological theories of musical creativity. Psychology of Music, 35(1), 144-168. https://doi.org/10.1177/0305735607068892

*Krahé, C., Hahn, U., \& Whitney, K. (2015). Is seeing (musical) believing? The eye versus the ear in emotional responses to music. Psychology of Music, 43(1), 140-148. https://doi.org/ $10.1177 / 0305735613498920$

Larson, S. (2005). Composition versus improvisation? Journal of Music Theory, 49(2), 241-275.

Lawendowski, R., Kierzkowski, M., \& Karasiewicz, K. (2016). Percepcja elementów muzycznych przez uczniów dyslektycznych [Perception of musical elements in students with dyslexia]. Psychologia Wychowawcza [Educational Psychology], 51(9), 26-43. https://doi.org/10.5604/ 00332860.1211479

*Lehmann, A. C. (1997). Research note: Affective responses to everyday life events and music listening. Psychology of Music, 25(1), 84-90. https://doi.org/10.1177/0305735697251007

*Liljeström, S., Juslin, P. N., \& Västfjäll, D. (2012). Experimental evidence of the roles of music choice, social context, and listener personality in emotional reactions to music. Psychology of Music, 41(5), 579-599. https://doi.org/10.1177/0305735612440615

*Love, K. G., \& Barrett, M. S. (2015). A case study of teaching and learning strategies in an orchestral composition masterclass. Psychology of Music, 44(4), 830-846. https://doi.org/10. $1177 / 0305735615594490$

*Love, K. G., \& Barrett, M. S. (2018). Signature pedagogies for musical practice: A case study of creativity development in an orchestral composers' workshop. Psychology of Music, 47(4), 551-567. https://doi.org/10.1177/0305735618765317

*Luck, G., Toiviainen, P., Erkkilä, J., Lartillot, O., Riikkilä, K., Mäkelä, A., ... Värri, J. (2007). Modelling the relationships between emotional responses to, and musical content of, music therapy improvisations. Psychology of Music, 36(1), 25-45. https://doi.org/10.1177/030573 5607079714

*Lundqvist, L. O., Carlsson, F., Hilmersson, P., \& Juslin, P. N. (2008). Emotional responses to music: Experience, expression, and physiology. Psychology of Music, 37(1), 61-90. https://doi.org/10.1177/0305735607086048

*MacDonald, R., Byrne, C., \& Carlton, L. (2016). Creativity and flow in musical composition: An empirical investigation. Psychology of Music, 34(2), 292-306. https://doi.org/10.1177/ 0305735606064838

*MacIntyre, P. D., \& Potter, G. K. (2013). Music motivation and the effect of writing music: A comparison of pianists and guitarists. Psychology of Music, 42(3), 403-419. https:// doi.org/10.1177/0305735613477180 
*Madeira, L. R. B., Araújo, M. V., Hein, C. F., \& Marinho, H. (2017). Adaptation of a SelfRegulated Practice Behaviour Scale for Portuguese music students. Psychology of Music, 46(6), 795-812. https://doi.org/10.1177/0305735617724884

*Maher, T. F., \& Berlyne, D. E. (1982). Verbal and exploratory responses to melodic musical intervals. Psychology of Music, 10(1), 11-27. https://doi.org/10.1177/0305735682101002

Manturzewska, M. (1990). Psychologia muzyki-kierunki i etapy rozwoju [The psychology of music - directions and stages of development]. In M. Manturzewska \& H. Kotarska (Eds.), Wybrane zagadnienia z psychologii muzyki [Selected issues in the psychology of music] (pp. 11-24). Warsaw: Wydawnictwa Szkolne i Pedagogiczne.

*Mawang, L. L., Kigen, E. M., \& Mutweleli, S. M. (2018). Achievement goal motivation and cognitive strategies as predictors of musical creativity among secondary school music students. Psychology of Music. Advanced online publication. https://doi.org/10.1177/ 0305735618805837

*Mazur, Z., \& Laguna, M. (2019). The role of affect in practicing a musical instrument: A systematic review of the literature. Psychology of Music, 47(6), 848-863. https://doi.org/ $10.1177 / 0305735619861831$

*McPherson, G. E., Osborne, M. S., Evans, P., \& Miksza, P. (2017). Applying self-regulated learning microanalysis to study musicians' practice. Psychology of Music, 47(1), 18-32. https://doi.org/10.1177/0305735617731614

Mielke, S. (2016). Mental practice in music performance: A literature-based glossary and taxonomy. School of Music Faculty of Arts University of Ottawa, Canada.

*Miksza, P. (2010). Relationships among achievement goal motivation, impulsivity, and the music practice of collegiate brass and woodwind players. Psychology of Music, 39(1), 50-67. https://doi.org/10.1177/0305735610361996

*Miksza, P. (2013). The effect of self-regulation instruction on the performance achievement, musical self-efficacy, and practicing of advanced wind players. Psychology of Music, 43(2), 219-243. https://doi.org/10.1177/0305735613500832

*Nielsen, S. (1999). Regulation of learning strategies during practice: A case study of a single church organ student preparing a particular work for a concert performance. Psychology of Music, 27(2), 218-229. https://doi.org/10.1177/0305735699272015

*Nielsen, S. G. (2004). Strategies and self-efficacy beliefs in instrumental and vocal individual practice: A study of students in higher music education. Psychology of Music, 32(4), 418-431. https://doi.org/10.1177/0305735604046099

Nogaj, A. A., Czarnecka, I., \& Ossowski, R. (2019). Differences in stress coping styles and social skills between classical and jazz musicians. Roczniki Psychologiczne [Annals of Psychology], 22(4), 337-352. http://dx.doi.org/10.18290/rpsych.2019.22.4-3

*Odendaal, A. (2015). (Mis)matching perceptual learning styles and practicing behavior in tertiary level Western Classical instrumentalists. Psychology of Music, 44(3), 353-368. https:// doi.org/10.1177/0305735614567933

Ockelford, A. (2016). Beyond music psychology. In S. Hallam, I. Cross, \& M. Thaut (Eds.), The Oxford handbook of music psychology (2nd ed.). Oxford: Oxford University Press. https://doi.org/10.1093/oxfordhb/9780198722946.013.52

*Perkins, R., \& Williamon, A. (2013). Learning to make music in older adulthood: A mixed-methods exploration of impacts on wellbeing. Psychology of Music, 42(4), 550-567. https://doi.org/10.1177/0305735613483668

*Pike, P. D. (2017). Self-regulation of teenaged pianists during at-home practice. Psychology of Music, 45(5), 739-751. https://doi.org/10.1177/0305735617690245 
Podlipniak, P. (2019). The neo-Pythagorean view of musical structure in the light of music psychology. Roczniki Psychologiczne [Annals of Psychology], 22(2), 121-134. https://doi.org/ 10.18290/rpsych.2019.22.2-2

PoM: Psychology of Music. (2019). Journal Info. Aims and scope. https://journals.sagepub. com/aims-scope/POM

*Priest, T. (2006). Self-evaluation, creativity, and musical achievement. Psychology of Music, 34(1), 47-61. https://doi.org/10.1177/0305735606059104

Rakowski, A. (2001). What is music? Musicae Scientiae, 5(2_suppl.), 125-130. https://doi.org/ $10.1177 / 10298649010050$ S217

*Rawlings, D., \& Leow, S. H. (2008). Investigating the role of psychoticism and sensation seeking in predicting emotional reactions to music. Psychology of Music, 36(3), 269-287. https://doi.org/10.1177/0305735607086042

*Rickard, N. S. (2004). Intense emotional responses to music: A test of the physiological arousal hypothesis. Psychology of Music, 32(4), 371-388. https://doi.org/10.1177/0305735604046096

*Rosemann, S., Altenmüller, E., \& Fahle, M. (2015). The art of sight-reading: Influence of practice, playing tempo, complexity and cognitive skills on the eye-hand span in pianists. Psychology of Music, 44(4), 658-673. https://doi.org/10.1177/0305735615585398

Ryan, T. G., \& Brown, K. (2012). Musical creativity: Measures and learning. Journal of Elementary Education, 22(2), 105-120.

*Saiz-Clar, E., \& Reales, J. M. (2017). Predicting emotional response to music through a compound neural network. Psychology of Music, 46(2), 222-237. https://doi.org/10.1177/ 0305735617705452

* Sakakibara, A. (2012). A longitudinal study of the process of acquiring absolute pitch: A practical report of training with the 'chord identification method.' Psychology of Music, 42(1), 86-111. https://doi.org/10.1177/0305735612463948

*Sakka, L. S., \& Juslin, P. N. (2017). Emotional reactions to music in depressed individuals. Psychology of Music, 46(6), 862-880. https://doi.org/10.1177/0305735617730425

*Sandgren, M. (2018). How modes of instrumental practice are distributed in three musical genres and among vocalists and instrumentalists at music colleges. Psychology of Music, 47(5), 767-778. https://doi.org/10.1177/0305735618765299

*Sandstrom, G. M., \& Russo, F. A. (2011). Absorption in music: Development of a scale to identify individuals with strong emotional responses to music. Psychology of Music, 41(2), 216-228. https://doi.org/10.1177/0305735611422508

*Sawyer, R. K. (2006). Group creativity: Musical performance and collaboration. Psychology of Music, 34(2), 148-165. https://doi.org/10.1177/0305735606061850

*Schatt, M. D. (2017). Middle school band students' self-determination to practice. Psychology of Music, 46(2), 208-221. https://doi.org/10.1177/0305735617705008

Schäfer, T., Sedlmeier, P., Städtler, C., \& Huron, D. (2013). The psychological functions of music listening. Frontiers in Psychology, 4, 511. https://doi.org/10.3389/fpsyg.2013.00511

*Seddon, F. A., \& O’Neill, S. A. (2001). An evaluation study of computer-based compositions by children with and without prior experience of formal instrumental music tuition. Psychology of Music, 29(1), 4-19. https://doi.org/10.1177/0305735601291002

*Seddon, F. A., \& O’Neill, S. A. (2006). How does formal instrumental music tuition (FIMT) impact on self- and teacher-evaluations of adolescents' computer-based compositions? Psychology of Music, 34(1), 27-45. https://doi.org/10.1177/0305735606059103 
*Simonton, D. K. (1994). Computer content analysis of melodic structure: Classical composers and their compositions. Psychology of Music, 22(1), 31-43. https://doi.org/10.1177/03057 35694221003

*Sims, W. L. (1988). Movement responses of pre-school children, primary grade children, and preservice classroom teachers to characteristics of musical phrases. Psychology of Music, 16(2), 110-127. https://doi.org/10.1177/0305735688162002

Sloboda, J. A., Davidson, J. W., Howe, M. J. A., \& Moore, D. G. (1996). The role of practice in the development of performing musicians. British Journal of Psychology, 87, 287-309.

*Sloboda, J. A. (1991). Music structure and emotional response: Some empirical findings. Psychology of Music, 19(2), 110-120. https://doi.org/10.1177/0305735691192002

*Smith, B. P. (2005). Goal orientation, implicit theory of ability, and collegiate instrumental music practice. Psychology of Music, 33(1), 36-57. https://doi.org/10.1177/0305735605048013

*Sovansky, E. E., Wieth, M. B., Francis, A. P., \& McIlhagga, S. D. (2014). Not all musicians are creative: Creativity requires more than simply playing music. Psychology of Music, 44(1), 25-36. https://doi.org/10.1177/0305735614551088

*Stambaugh, L. A. (2012). Differential effects of cognitive load on university wind students' practice. Psychology of Music, 41(6), 749-763. https://doi.org/10.1177/0305735612449505

*Susino, M., \& Schubert, E. (2018). Cultural stereotyping of emotional responses to music genre. Psychology of Music, 47(3), 342-357. https://doi.org/10.1177/0305735618755886

*Swanwick, K. (1973). Musical cognition and aesthetic response. Psychology of Music, 1(2), 7-13. https://doi.org/10.1177/030573567312001

*Valenzuela, R., Codina, N., \& Pestana, J. V. (2017). Self-determination theory applied to flow in conservatoire music practice: The roles of perceived autonomy and competence, and autonomous and controlled motivation. Psychology of Music, 46(1), 33-48. https://doi.org/ $10.1177 / 0305735617694502$

*Waterman, M. (1996). Emotional responses to music: Implicit and explicit effects in listeners and performers. Psychology of Music, 24(1), 53-67. https://doi.org/10.1177/0305735696241006

*Wen, Y. C., \& Tsai, C.-G. (2016). The effect of harmonization on cortical magnetic responses evoked by music of rapidly changing tonalities. Psychology of Music, 45(1), 22-35. https://doi.org/10.1177/0305735616639386

*Williams, D., Kirke, A., Miranda, E. R., Roesch, E., Daly, I., \& Nasuto, S. (2014). Investigating affect in algorithmic composition systems. Psychology of Music, 43(6), 831-854. https:// doi.org/10.1177/0305735614543282

*Wilson, G. B., \& MacDonald, R. A. R. (2012). The sign of silence: Negotiating musical identities in an improvising ensemble. Psychology of Music, 40(5), 558-573. https://doi.org/10.1177/ 0305735612449506

*Yinger, O. S., \& Springer, D. G. (2018). Using psycholinguistic inquiry to measure emotional response to music: A feasibility study. Psychology of Music, 47(4), 606-614. https://doi.org/$10.1177 / 0305735618765292$

Zimmerman, B. J. (2002). Becoming a self-regulated learner: An overview. Theory into Practice, 41(2), 64-70. 